\title{
The effect of temperature on the development of encapsulated embryos of Concholepas concholepas along a latitudinal cline
}

\author{
Miriam Fernández ${ }^{1,2, *}$, Ricardo Calderón ${ }^{1}$, Juan M. Cancino ${ }^{3}$, Katherine Jeno ${ }^{1}$ \\ ${ }^{1}$ Estación Costera de Investigaciones Marinas, Center for Advanced Studies in Ecology and Biodiversity (CASEB), and \\ ${ }^{2}$ International Associated Laboratory ‘Dispersal and Adaptation in Marine Species' (Station Biologique de Roscoff and \\ CASEB), Departemento de Ecología, Facultad de Ciencias Biológicas, Pontificia Universidad Católica, Alameda 340, \\ Casilla 114-D, Santiago, Chile \\ ${ }^{3}$ Departamento de Ecología Costera, Facultad de Ciencias, Universidad Católica de la Santísima Concepción, \\ Concepción, Chile
}

\begin{abstract}
Encapsulating species face more constraints than active brooders in adjusting oxygen supply to the needs of the embryos. Therefore, the packing of embryos in gelatinous egg masses or egg capsules is expected to be adjusted to the temperature and oxygen conditions that the embryos are likely to experience. We studied the patterns of embryo packing (number of embryos per unit area) of the gastropod, Concholepas concholepas, from 14 sites over an extended geographic area spanning $22^{\circ}$ of latitude off the coast of Chile. A clear break in the patterns of embryo packing was found at approximately 29 to $30^{\circ} \mathrm{S}$. Capsules collected at the sites located north of this break exhibited significantly fewer embryos per unit area than capsules from southern sites. Embryo packing is correlated with mean temperature shortly before egg deposition. A set of laboratory experiments were conducted to determine if the effects of temperature reside in females (incubating females collected in 2 different sites at a common temperature) or in embryos (incubating capsules at different temperatures). Laboratory experiments showed that temperature does not affect the number of embryos that successfully develop in the capsules within the tolerated range of temperatures, but does influence developmental success at temperatures that are extreme for the sites of the sample population. Our results suggest that packing and protection of embryos in marine invertebrates might be linked to the capacity to supply oxygen to the brood, which can have important consequences for the distribution of brooding and encapsulating species across temperature gradients.
\end{abstract}

KEY WORDS: Brooding · Concholepas concholepas · Embryo development · Encapsulated development · Oxygen · Temperature

- Resale or republication not permitted without written consent of the publisher

\section{INTRODUCTION}

Over the last 2 decades several studies have shown that oxygen is a limiting factor in the aggregation of embryos in aquatic systems (Strathmann \& Strathmann 1995, Cohen \& Strathmann 1996, Crump 1996), directly controlling embryonic development (Strathmann \& Strathmann 1995, Cohen \& Strathmann 1996, Cancino et al. 2003). Oxygen also seems to affect shell calcification in marine gastropods (e.g. Cancino et al. 2000, 2003), which may have enormous consequences on subsequent survival. The problem of oxygen acquisition imposed by aquatic systems can also help to explain the proportional positive relationship between the number of embryos and the surface area of the capsule in marine gastropods (genus Conus; Perron \& Corpuz 1982). This evidence suggests that the strong oxygen limitation exhibited by both embryo masses 
and capsules in aquatic systems may be an important evolutionary force affecting the capacity of the parents to aggregate the embryos, the patterns of embryo packing and the spread of parental care in aquatic systems in general (Strathmann \& Strathmann 1982).

Several studies have shown the effects of oxygen and temperature on embryo oxygen demand and embryo development under laboratory conditions for different types of embryo aggregations (jelly, capsules, crab egg masses; Cohen \& Strathmann 1996, Baeza \& Fernández 2002, Lardies \& Fernández 2002, Brante et al. 2003, Cancino et al. 2003). There is also evidence that parental behavior and the cost of brooding is affected by the oxygen demand of the embryos. For example, female crabs increase the frequency of brooding behaviors that help provide oxygen to the embryos (e.g. abdominal flapping) to compensate for the higher oxygen demand of later embryonic stages, thereby increasing the costs of brooding (energetic cost; Baeza \& Fernández 2002, Brante et al. 2003). Similar changes in patterns of brooding behavior and cost in brachyuran crabs are correlated with temperaturedependent embryo oxygen demands (Brante et al. 2003). The positive relationship between temperature and the cost of brooding suggests that the capacity to aggregate embryos in the ocean, and therefore to provide parental care, may be favored at low temperature (Brante et al. 2003). This prediction is strongly based on studies conducted on brachyuran crabs, which always show active brooding behaviors directed towards providing oxygen to the brood (Baeza \& Fernández 2002, Brante et al. 2003). However, aggregating embryos is also costly for passive brooding species (e.g. gelatinous embryo masses; Lee \& Strathmann 1998). Since passive brooding species face more constraints in adjusting oxygen supply to the needs of the embryos, it is expected that the packing of embryos in gelatinous egg masses or egg capsules is adjusted to the temperature and oxygen conditions that the embryos are likely to experience. We do not disregard other environmental variables that are correlated with temperature and that may also shape embryo packing.

The effects of temperature on embryo packing and clutch size among marine invertebrates are less clear, despite the following evidence for marine invertebrates in general and gastropods that exhibit encapsulated development, in particular. (1) Temperature affects oxygen demand of the embryos (e.g. Brante et al. 2003). (2) The capsule walls limit oxygen diffusion (Cancino et al. 2000, Brante 2006). (3) Intracapsular oxygen conditions affect embryo development and, therefore, clutch size (Cancino et al. 2003). (4) There is a positive relationship between the number of embryos and surface area of the capsule (Perron \& Corpuz 1982). This evidence suggests that oxygen conditions could have shaped re- productive attributes, including clutch size, in gastropod species that encapsulate embryos. We studied the patterns of embryo packing of Concholepas concholepas (Mollusca: Muricidae) from 14 sites over an extended geographic area spanning $22^{\circ}$ of latitude off the coast of Chile. The response variable was the number of embryos packed per unit area of capsule. This extended geographic region also allowed us to relate temperature to patterns of embryo packing and to draw indirect inferences about the cost of aggregating embryos. A set of laboratory experiments was conducted to determine whether the effects of temperature reside in females, by affecting embryo assignation depending on seawater temperature of the site before egg deposition, or in embryos, by affecting embryo mortality during intracapsular development. Concholepas concholepas is a good model to address these problems because (1) it shows an extended latitudinal distribution $\left(5\right.$ to $\left.54^{\circ} \mathrm{S}\right)$, (2) it encapsulates embryos but does not exhibit ovophagia or adelphophagia (Gallardo 1973), which can be alternative determinants of clutch size, and (3) capsules and females can be easily manipulated under laboratory conditions. In addition, C. concholepas is heavily exploited (Bustamante \& Castilla 1987) to the point that harvesting negatively affects capsule deposition (Manríquez \& Castilla 2001). Therefore, the identification of geographic regions offering different environmental conditions for embryo packing is critical. However, the present study has implications which go beyond the significance for this model species.

\section{MATERIALS AND METHODS}

Mature Concholepas concholepas females (>50 mm shell length) collectively deposit capsules in small aggregations in areas characterized by strong water flow in both intertidal and subtidal zones (Castilla \& Cancino 1976, Lopez \& Varela 1988). Embryos develop within the capsules for approximately $30 \mathrm{~d}$ (Gallardo 1973, 1979). After hatching, a free larval phase develops in the plankton for approximately 60 to $90 \mathrm{~d}$ (DiSalvo 1988). Although under laboratory conditions C. concholepas females deposit egg capsules throughout the year, reproduction in nature is seasonal and varies along the coast of Chile (Castilla \& Cancino 1976, López \& Varela 1988). The capsules contain between a few hundred to more than 14000 embryos (Gallardo 1973, Castilla \& Cancino 1976). The total number of embryos deposited per capsule is positively correlated with capsule size, which in turn is positively correlated with female size (Gallardo 1973, Castilla \& Cancino 1976).

Latitudinal pattern of embryo packing. To investigate the patterns of embryo packing in capsules of 
Concholepas concholepas between sites in the biogeographic region associated with the Humboldt Current (Strub et al. 1998), capsules were collected during the reproductive season (May to November) from the lowest intertidal zone of wave-exposed areas. Fourteen sites were sampled from northern Chile (Iquique, $20^{\circ} 53^{\prime} \mathrm{S}$ ) to Chiloé Island (Ancud, $42^{\circ} 02 ' \mathrm{~S}$; Fig. 1) between 2003 and 2005. One capsule was collected from each aggregation found and was assumed to have been placed by a single female. The number of capsules analyzed per site is shown in Table 1. After collection, the capsules were preserved in $75 \%$ alcohol for later analysis. In the laboratory, the length and width of each capsule was measured to $0.1 \mathrm{~mm}$ and the number of embryos in each capsule was counted under a microscope. Embryos were spread evenly on a dish divided into 113 equally sized squares, and all the embryos were counted in 16 randomly selected squares from which the total egg number was estimated. The size of the capsules ranged from 7.5 to $23.0 \mathrm{~mm}$ (mean $\pm \mathrm{SD}=14.8 \pm 3.7 \mathrm{~mm}$ ) in length. Since the number of embryos per capsule was positively correlated with capsule size (length: $\mathrm{r}=0.43, \mathrm{n}=$ $399, p<0.0001)$, the number of embryos was standardized per unit area $\left(\mathrm{mm}^{2}\right)$ of the capsule's surface and used as the response variable. Capsule area was selected because no correlation was found between number of embryos per unit of capsule surface area and capsule length ( $\mathrm{r}=0.11, \mathrm{n}=283, \mathrm{p}=0.27$ ) and because capsule area is likely to be an indicator of oxygen exchange surface (Perron \& Corpuz 1982). Capsule surface area was estimated assuming the shape of a cylinder. Mean number of embryos per $\mathrm{mm}^{2}$ of capsule area was compared across sites using 1-way ANOVA. At most sites we found capsules containing embryos in early developmental stages as well as capsules containing embryos in late developmental stages; however, at some sites capsules containing embryos in only 1 developmental stage were found (Table 1). Although according to Gal-

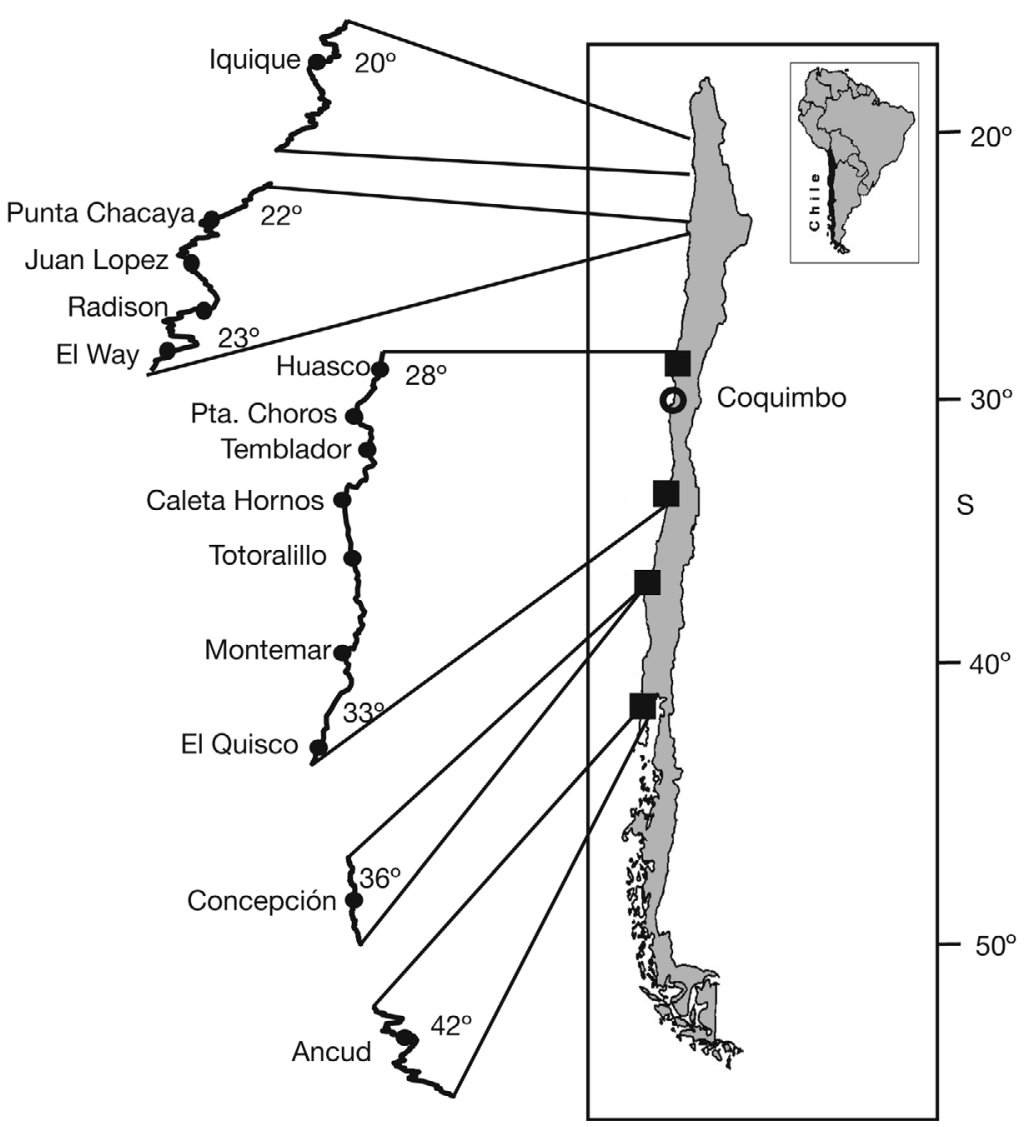

Fig. 1. Study area on the coast of Chile, which encompasses $22^{\circ}$ of latitude, showing the 14 study sites

Table 1. Concholepas concholepas. The 14 study sites where capsules containing early and late stage embryos were collected. Latitude (lat.) of the site, mean water temperature (MWT) in ${ }^{\circ} \mathrm{C}( \pm \mathrm{SE})$, number of capsules (early and late) analyzed for each embryo stage and total no. of capsules are given; nc: no capsules found

\begin{tabular}{|c|c|c|c|c|c|}
\hline \multirow[t]{2}{*}{ Site } & \multirow{2}{*}{ Lat. $\left({ }^{\circ} \mathrm{S}\right)$} & \multirow{2}{*}{$\begin{array}{l}\text { MWT } \\
( \pm \text { SE })\end{array}$} & \multicolumn{3}{|c|}{ No. capsules } \\
\hline & & & Early stage & Late stage & Total \\
\hline Iquique & $20^{\circ} 53^{\prime}$ & $16.51(0.81)$ & 18 & 5 & 23 \\
\hline Punta Chacaya & $22^{\circ} 58^{\prime}$ & $15.58(0.61)$ & 15 & 5 & 20 \\
\hline Juan Lopez & $23^{\circ} 28^{\prime}$ & $15.42(0.47)$ & 14 & 5 & 19 \\
\hline Radison & $23^{\circ} 40^{\prime}$ & $14.19(0.19)$ & 14 & 11 & 25 \\
\hline El Way & $23^{\circ} 42^{\prime}$ & $14.22(0.54)$ & 4 & 5 & 9 \\
\hline Huasco & $28^{\circ} 24^{\prime}$ & $13.48(0.63)$ & 9 & 20 & 29 \\
\hline Punta Choros & $29^{\circ} 15^{\prime}$ & $13.75(1.16)$ & 58 & nc & 58 \\
\hline Temblador & $29^{\circ} 28^{\prime}$ & $13.33(0.45)$ & 7 & 7 & 14 \\
\hline Caleta Hornos & $29^{\circ} 39^{\prime}$ & $11.52(0.25)$ & nc & 34 & 34 \\
\hline Totoralillo & $30^{\circ} 03^{\prime}$ & $13.49(0.67)$ & 24 & 6 & 30 \\
\hline Montemar & $32^{\circ} 57^{\prime}$ & $13.24(0.19)$ & 8 & 6 & 14 \\
\hline El Quisco & $33^{\circ} 23^{\prime}$ & $12.61(0.32)$ & nc & 16 & 16 \\
\hline Concepción & $36^{\circ} 48^{\prime}$ & $12.01(0.32)$ & 13 & $\mathrm{nc}$ & 15 \\
\hline Ancud & $42^{\circ} 02^{\prime}$ & $10.50(0.34)$ & nc & 17 & 17 \\
\hline
\end{tabular}


lardo (1973), the number of encapsulated embryos in Concholepas concholepas does not vary during embryo development, the comparisons were conducted independently for each embryo stage as well as with pooled samples of capsules containing early and late stage embryos.

To assess the effects of temperature on the number of encapsulated embryos per unit area of capsule along the study region, temperature data loggers were installed at all study sites $30 \mathrm{~d}$ before the capsules were collected. Data loggers were always placed in the lowest intertidal zone of exposed rocky platforms. Within this region no latitudinal patterns were found in aerial exposure (Finke et al. 2007); therefore, the pattern of mean temperature was not expected to be biased by aerial or water temperature throughout the latitudinal gradient. Mean temperature was calculated using all data points obtained during this period (Table 1). Correlation analyses (Pearson) were conducted to assess the relationship between temperature and number of eggs per $\mathrm{mm}^{2}$ of capsule area for each embryo stage and all capsules (pooling both embryo stages).

Role of temperature in clutch size determination in Concholepas concholepas. Since temperature is correlated with the number of embryos assigned by females $\mathrm{mm}^{-2}$ of capsule area in nature (see 'Results'), laboratory experiments were conducted to determine whether the effect of temperature resides in females through the effects of environmental temperature before egg deposition on patterns of embryo packing - or in embryos - through the effects on embryo mortality during intracapsular development. Two experiments were conducted to identify the relative importance of each mechanism.

Effects of temperature on females: Since our field studies show that local temperature at the study site a month before egg deposition is a good predictor of the number of embryos that females deposit per unit area of capsule (see 'Results'), a laboratory experiment was designed with the goal of removing the effect of temperature of the site of origin by acclimating females for between 4 and 6 mo to a common constant temperature $\left(12^{\circ} \mathrm{C}\right)$. Female Concholepas concholepas were collected from 2 sites within our study area, one situated in the northern region (at $29^{\circ} \mathrm{S}$ ), where females deposit fewer embryos per unit area of capsule, and the second in the southern region (at $42^{\circ} \mathrm{S}$ ). Experimental animals were transported to the Laboratorio Costero Lenga $\left(36^{\circ} 44^{\prime} \mathrm{S}\right.$, $73^{\circ} 11^{\prime} \mathrm{W}$ ) shortly after collection, where females from different sites of origin were placed in 5001 aquaria. Animals were fed ad libitum with clams (Protothaca thaca and Semece solida) and were maintained at constant temperature and salinity ( $33 \pm 1 \%$ ) under air flow.

After the acclimation period we collected the capsules that females deposited in the aquaria. Recently deposited capsules $(<36 \mathrm{~h})$ were removed and assigned to 5 temperature treatments: 6, 9, 12, 15 and $18^{\circ} \mathrm{C}$, to assess the effects of temperature on developmental success. These temperatures are within the temperature range to which capsules are exposed under natural conditions. The capsules from the different sites of origin were placed in small containers (0.5 l). Four containers per site of origin and incubation temperature were used, and approximately 20 capsules from different females were incubated in each container. Thermostats maintained constant temperature. Filtered seawater was replaced every other day during the incubation period. The capsules were maintained with constant aeration. Embryo development was monitored regularly until the pre-veliger stage was reached, at which time 1 capsule was sampled from each treatment combination. Most of the capsules were sampled during the experiment, but only 1 per container was used to record (1) length and width of the capsule, and (2) number of embryos (see protocol previously described). The remaining capsules were only used to monitor development. At some temperatures $\left(6,9\right.$ and $\left.18^{\circ} \mathrm{C}\right)$ embryo mortality occurred, preventing us from conducting a full-factorial ANOVA. For this reason, 2 independent analyses were conducted. First, 1-way ANOVAs were conducted for each site of origin to compare the effect of temperature on the mean final number of embryos per unit area of capsule among temperature treatments in which development occurred. Since development at the different temperatures depended on the site of origin, different incubation temperatures were compared for the northern $\left(12,15\right.$ and $\left.18^{\circ} \mathrm{C}\right)$ and southern origins $(9,12$, $15^{\circ} \mathrm{C}$ ). A 2 -way ANOVA was then used to compare the mean number of embryos per unit area of capsule between sites of origin and temperatures for the 2 temperatures at which development was observed (12 and $15^{\circ} \mathrm{C}$ ). Data were not transformed because the assumptions of the model were met. Tukey's HSD tests were used to assess differences among treatments.

Effects of temperature on embryos: Since the experiment described in the previous section does not distinguish the effect of temperature on females (before capsule deposition) from the effect on the embryos (survival during intracapsular development), a second laboratory experiment was conducted to determine whether the number of embryos deposited by females per unit area of capsule (initial number) changed during intracapsular development (final number) and to assess whether the changes were temperature dependent. Recently deposited capsules of Concholepas concholepas were collected from the intertidal zone of Las Cruces $\left(33^{\circ} \mathrm{S}\right)$ in July 2003. Immediately after collection the capsules from different females were transported to the laboratory and 
haphazardly assigned to either the 12 or the $15^{\circ} \mathrm{C}$ temperature treatment. Thermostats maintained constant temperature. Five and six 11 containers were used for 12 and $15^{\circ} \mathrm{C}$ respectively; 6 capsules were assigned haphazardly to each container. One capsule was removed from each container at both the beginning of the experiment (initial time) and the end of the experiment (final time). One container from the $15^{\circ} \mathrm{C}$ treatment was lost during the experiment. The experiment was carried out for 60 and $40 \mathrm{~d}$ at 12 and $15^{\circ} \mathrm{C}$, respectively. The capsules were maintained with filtered seawater and constant aeration. Water was exchanged every other day throughout development. Embryo development was monitored regularly. Before hatching (final time), 1 capsule was sampled per container. Length and width (to $0.1 \mathrm{~mm}$ ) of the capsule and total number of embryos were recorded for each capsule sampled for each container, temperature and time. The number of embryos was estimated as described in 'Latitidinal pattern of embryo packing' above. After calculating capsule area (see 'Latitudinal pattern of embryo packing' above) the number of embryos $\mathrm{mm}^{-2}$ of capsule area was estimated. A 2-way ANOVA was used to assess the effects of temperature and developmental time (initial and final) on the mean number of embryos per unit area of capsule. The data met the assumptions of the ANOVA model. Tukey's HSD tests were used to assess differences among treatments.

\section{RESULTS}

\section{Latitudinal pattern of embryo packing}

Significant differences in the mean number of embryos per unit area of capsule were detected among sites $(F=50.9, \mathrm{df}=13,310, \mathrm{p}=0.001)$, showing a clear break at approximately 29 to $30^{\circ} \mathrm{S}$ (Fig. 2A). Capsules collected at the sites located north of $29^{\circ} 28^{\prime}$ S exhibited significantly fewer embryos per unit area than capsules from sites south of $29^{\circ} 39^{\prime} \mathrm{S}(\mathrm{p}<0.05)$. No differences were detected among the 8 sites sampled north of $29^{\circ} 28^{\prime} \mathrm{S}$ or among the 6 sites sampled south of $29^{\circ} 39^{\prime} \mathrm{S}$ $(\mathrm{p}>0.05)$. The pattern described above was not affected by the fact that some sites had capsules containing only early or late stage embryos (Table 1) because a break in the mean number of embryos per unit area of capsule was still found between 29 and $30^{\circ} \mathrm{S}$ when early and late stage embryos were analyzed separately. The mean number of embryos per unit area of capsule was significantly lower in sites north of 29 to $30^{\circ} \mathrm{S}$ than in the southern sites for both embryo stages (early: $F=$ 18.05, df $=10,173, p=0.001$; late: $F=27.13, \mathrm{df}=11,126$, $\mathrm{p}=0.001$; Fig. 2B). No significant differences were detected in the mean number of early (or late) embryos

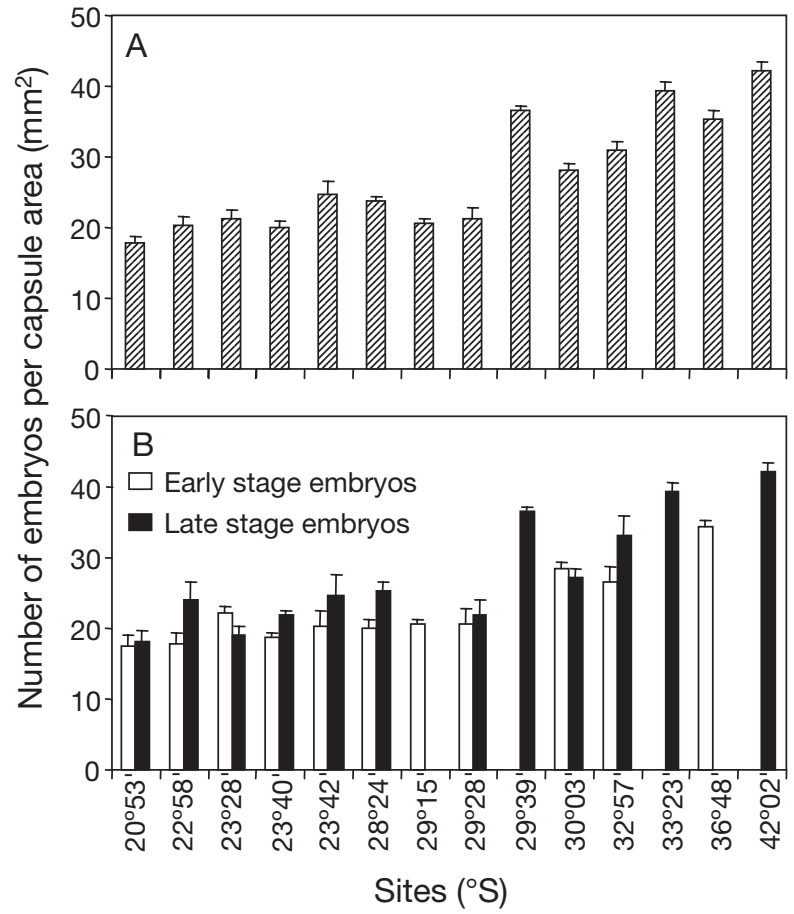

Fig. 2. Concholepas concholepas. Mean number of embryos per unit area $\left(\mathrm{mm}^{2}\right)$ of capsule at the 14 sites located between 20 and $42^{\circ} \mathrm{S}$ on the coast of Chile estimated (A) by pooling capsules containing early and late stage embryos and (B) for each stage separately. Vertical bars indicate $1 \mathrm{SE}$

per unit area of capsule either among sites located south of 29 to $30^{\circ} \mathrm{S}$ ( $\mathrm{p}>0.05$ ) or among sites sampled north of 29 to $30^{\circ} \mathrm{S}$ ( $\left.\mathrm{p}>0.05\right)$. Although mean capsule size was significantly different among sites $(F=76.84$, $\mathrm{df}=13,310, \mathrm{p}<0.0001$ ), the patterns of embryo packing were not related to capsule size (see 'Materials and Methods' for the analysis of the response variable). The sites showing the largest capsules (Punta Choro and Ancud) exhibited opposing patterns of embryo packing. Contrasting patterns of embryo packing were also found between the 2 sites showing the smallest capsules (Iquique and Totorallillo).

The observed trend in the mean number of embryos per unit area of capsule was correlated with the mean temperature at the study site before egg deposition. The mean number of early stage embryos per unit area of capsule was negatively correlated with temperature (early stage: $\mathrm{r}=0.87, \mathrm{n}=11, \mathrm{p}<0.001$; Fig. $3 \mathrm{~A}$ ), suggesting that females pack embryos differently depending on mean temperature or a correlate of temperature. The same trend was observed when capsules containing late stage embryos were analyzed (late stage: $\mathrm{r}=0.7, \mathrm{n}=11, \mathrm{p}<0.001$; Fig. 3A). Pooling all capsules, the relationship between mean temperature at the study site and mean number of embryos per unit area of capsule was also significant and negative (Fig. 3B). 


\section{Role of temperature in clutch size determination}

Temperature did not affect the mean number of embryos that developed in the 2 populations studied (northern and southern origin; Table 2). However, temperature tolerance of embryos differed with latitude of maternal population (Fig. 4). Embryo development did not occur at the 2 lowest experimental temperatures in capsules deposited by females collected in the northernmost location $\left(29^{\circ} \mathrm{S}\right)$, nor was any development noted at the lowest $\left(6^{\circ} \mathrm{C}\right)$ and highest temperatures $\left(18^{\circ} \mathrm{C}\right)$ in capsules deposited by females collected in the southern site. Regardless of the site of origin, $100 \%$ mortality was observed at $6^{\circ} \mathrm{C}$. Although temperature did affect the mean final number of embryos per unit area of capsule within each region, site of origin significantly influenced the number of embryos that reached the pre-veliger stage $(F=40.08, \mathrm{df}=1,12, \mathrm{p}<0.0001)$, when the 2 temperatures at which development occurred in both sites of origin $\left(12\right.$ and $\left.15^{\circ} \mathrm{C}\right)$ were compared. The mean final number of embryos incubated at 12 or $15^{\circ} \mathrm{C}$ was significantly lower in the capsules deposited by females collected in the northern $(34.5, \mathrm{SD}=1.91)$ than in the

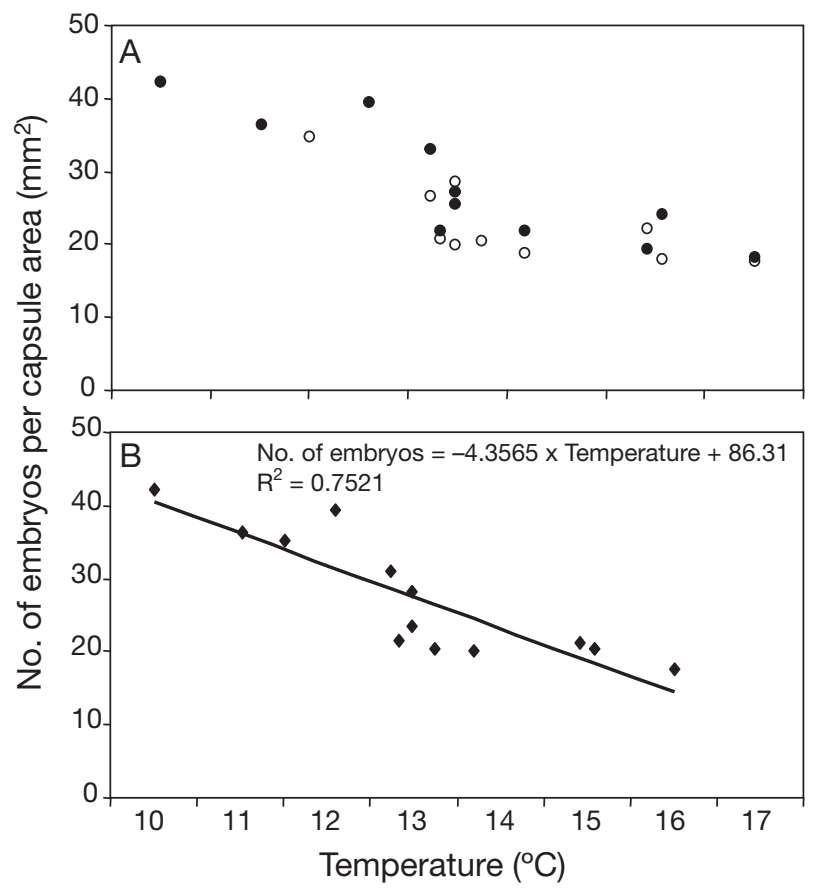

Fig. 3. Concholepas concholepas. Relationship between seawater temperature $\left({ }^{\circ} \mathrm{C}\right)$ and mean number of embryos per unit area $\left(\mathrm{mm}^{2}\right)$ of capsule estimated (A) for each stage separately (O: capsules containing early stage embryos, $\bullet$ : capsules containing late stage embryos) and (B) by pooling capsules containing early and late stage embryos $(n=14)$. Regression parameters are given in (B)
Table 2. Concholepas concholepas. Results of the 1-way ANOVAs conducted to assess the effects of incubation temperatures $\left(12\right.$ and $\left.15^{\circ} \mathrm{C}\right)$ of the capsules on the mean number of embryos per unit area $\left(\mathrm{mm}^{2}\right)$ of capsule that successfully developed for 2 sites of origin located to the north $\left(<30^{\circ} \mathrm{S}\right)$ and the south $\left(>30^{\circ} \mathrm{S}\right)$ of the break identified in our study. Since development at the different temperatures depended on the site of origin, different incubation temperatures were compared for individuals of northern origin $\left(12,15\right.$ and $\left.18^{\circ} \mathrm{C}\right)$ and southern origin $\left(9,12\right.$ and $\left.15^{\circ} \mathrm{C}\right)$

\begin{tabular}{|c|c|c|c|c|}
\hline $\begin{array}{l}\text { Site of } \\
\text { origin }\end{array}$ & $\begin{array}{c}\text { Source } \\
\text { of variation }\end{array}$ & df & $F$ & $\mathrm{p}$ \\
\hline \multirow[t]{2}{*}{$\begin{array}{l}\text { Northern origin } \\
\left(29^{\circ} \mathrm{S}\right)\end{array}$} & $\begin{array}{l}\text { Incubation } \\
\text { temperature }\end{array}$ & 2 & 1.172 & 0.353 \\
\hline & Error & 9 & & \\
\hline \multirow{2}{*}{$\begin{array}{l}\text { Southern origin } \\
\left(42^{\circ} \mathrm{S}\right)\end{array}$} & Incubation & 2 & 2.758 & 0.116 \\
\hline & Error & 9 & & \\
\hline
\end{tabular}

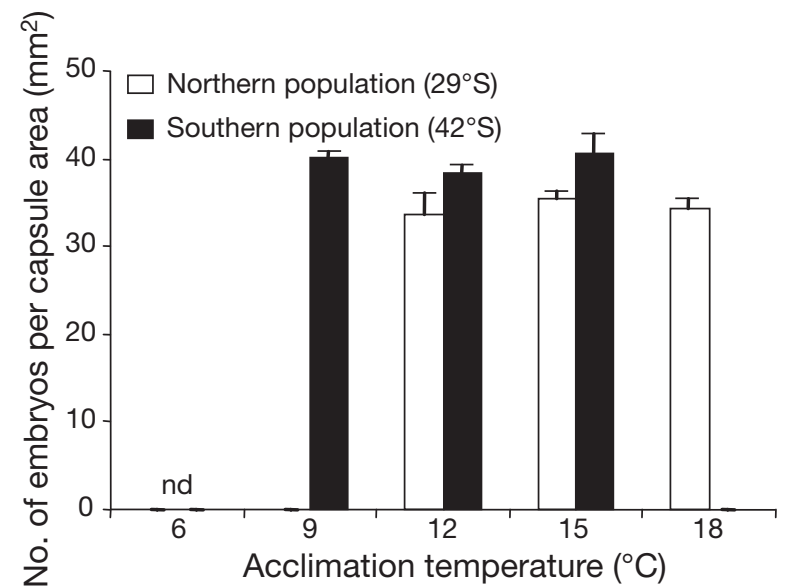

Fig. 4. Concholepas concholepas. Mean number of embryos per unit area $\left(\mathrm{mm}^{2}\right)$ of capsule developed at the end of the incubation experiment (pre-veliger stage) in capsules at 5 temperatures $\left(6,9,12,15\right.$ and $\left.18^{\circ} \mathrm{C}\right)$. Experimental capsules were deposited by females collected at 2 sites $\left(29^{\circ} \mathrm{S}\right.$ and $42^{\circ} \mathrm{S}$, northern and southern populations, respectively) and maintained at a common (acclimation) temperature of $12^{\circ} \mathrm{C}$ for 4 to 6 mo before capsules were laid; nd = no embryo development at that temperature. Vertical bars indicate $1 \mathrm{SE}$

southern region $(39.4, \mathrm{SD}=1.97 ; \mathrm{p}<0.05)$. The 2 experimental temperatures at which development occurred did not affect the mean number of embryos that reached pre-veliger stage per unit area of capsule $(F=4.51$, df $=1,12, \mathrm{p}=0.07)$. The interaction term was not significant $(F=1.15$, df $=1,12, \mathrm{p}=$ 0.306). Remarkably, the mean number of embryos $\mathrm{mm}^{-2}$ of capsule that attained pre-veliger stage did not show a difference between capsules sampled in the northern region and capsules deposited in the laboratory by females collected in the north $(t=0.97$, $\mathrm{df}=44, \mathrm{p}=0.33$ ). The same trend was found for the 
southern region $(t=1.86, \mathrm{df}=27, \mathrm{p}=0.27)$. Temperature did not affect the survival of Concholepas concholepas embryos during intracapsular development, since the mean number of embryos $\mathrm{mm}^{-2}$ did not change between initial and final time (Table 3, Fig. 5). The interaction between the 2 factors was not significant (Table 3).

\section{DISCUSSION}

The consistent patterns observed in our field sampling and laboratory experiments allowed the following conclusions. (1) Embryo packing (number of embryos packed per unit area of capsule) in capsules of Concholepas concholepas depends on the site of origin. (2) Temperature does not affect the number of embryos that successfully develop in the capsules, but (3) temperature is correlated with mean number of embryos per unit of area (embryo packing) and affects development, although the effect of temperature on

Table 3. Concholepas concholepas. Results of the 2-way ANOVA conducted to compare the mean initial number of embryos deposited by females per unit area of capsule and the final number of embryos that successfully developed between the 2 experimental temperatures 12 and $15^{\circ} \mathrm{C}$

\begin{tabular}{|lrcc|}
\hline Source of variation & $\mathrm{df}$ & $F$ & $\mathrm{p}$ \\
\hline Temperature & 1 & 3.540 & 0.311 \\
Developmental time & 1 & 0.604 & 0.580 \\
Interaction & 1 & 0.052 & 0.823 \\
Error & 17 & & \\
\hline
\end{tabular}

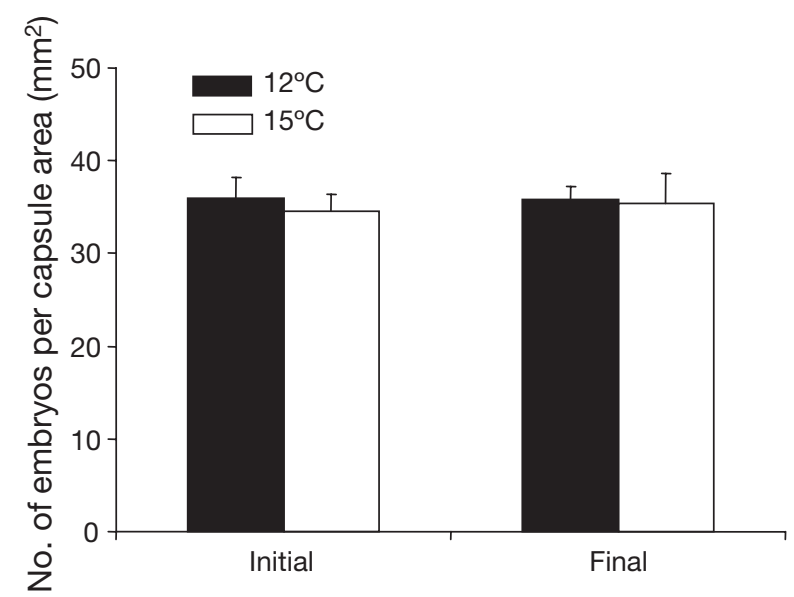

Fig. 5. Concholepas concholepas. Mean number of embryos per unit area of capsule $\left(\mathrm{mm}^{2}\right)$ in capsules collected at $33^{\circ} \mathrm{S}$ on the coast of Chile (southeastern Pacific Ocean) and incubated at 2 different temperatures $\left(12\right.$ and $\left.15^{\circ} \mathrm{C}\right)$ until hatching. Initial and final numbers of embryos per unit area of capsule are shown. Vertical bars indicate $1 \mathrm{SE}$ development depends on the site of origin of females. The break identified in the patterns of embryo packing and the effect of temperature on embryo developmental success suggests differences between populations, although we cannot distinguish whether this pattern is related to genetic differences or environmental responses.

Our study showed a break in embryo packing of the carnivore Concholepas concholepas between 29 and $30^{\circ} \mathrm{S}$. We hypothesize that a break in environmental variables or a break in the genetic structure of local populations could explain our results. Several lines of evidence provide support for the first argument. The clear break in embryo packing coincides with a clear break in eddy kinetic energy and equator-ward wind stress at $30^{\circ} \mathrm{S}$ (Hormazábal 2004) and with 2 contrasting regimes in chlorophyll concentration in coastal areas and offshore (Yuras et al. 2005). Moreover, contrasting patterns of recruitment and abundance of several key intertidal species occurred on each side of the break (Camus 1998, Broitman et al. 2001, Navarrete et al. 2005). Among the environmental variables that may affect the pattern of embryo packing, local temperature and oxygen concentration have been studied in aquatic systems (Strathmann \& Strathmann 1995, Cohen \& Strathmann 1996, Brante et al. 2003, Cancino et al. 2003). In our study area both variables can be influenced by upwelling persistence and strength, which breaks at 29 to $30^{\circ} \mathrm{S}$ (Hormazábal 2004), although the expected effects of oxygen concentration may occur only in subtidal areas (Helly \& Levin 2004). Our results clearly show that the number of embryos per unit area of capsule in intertidal zones is determined by local temperature before egg deposition, which, in turn, is strongly correlated with temperature during embryo development $(\mathrm{r}=0.75, \mathrm{n}=13, \mathrm{p}<0.04)$. We think that latitudinal patterns of embryo packing might respond to oxygen demand during embryonic development, as temperature affects embryo oxygen consumption (e.g. Brante et al. 2003) and oxygen is generally considered a limiting factor in embryo aggregation (Cohen \& Strathmann 1996, Crump 1996). Limits in the acquisition of oxygen in aquatic embryo aggregations have also been proposed as an explanation of the positive relationship between number of embryos and surface area of the capsule in marine gastropods (Perron \& Corpuz 1982). In our model species, limited oxygen supply through capsule walls (Brante 2006), which is expected to increase at higher temperatures due to the increase in embryo oxygen demand, may determine clutch size. This hypothesis is supported by evidence in the literature showing lower clutch sizes at higher temperatures in brachyuran crabs, which seems to be related to the higher cost of oxygen provision (Brante et al. 2003). Our results also 
suggest that the cost for C. concholepas of packing embryos increases with temperature, since fewer embryos can be packed per unit of extra embryonic material (capsule wall). Increases in encapsulation and brooding cost with temperature might affect the distribution of brooding species at low latitudes, which is in line with the higher prevalence of encapsulating and brooding species at low temperatures compared with those at high temperatures (Thorson 1950, Gallardo \& Penchazadeh 2001). These results suggest that different strategies in the way marine invertebrates pack and protect embryos might be shaped by the capacity to supply oxygen to the brood, and this depends on temperature (Strathmann \& Strathmann 1982). However, we do not disregard the effects of other environmental factors that might be correlated with temperature, such as metabolites produced by the embryos or development rates of protozoa or bacteria (Cancino et al. 2000).

Although we suggest that the latitudinal patterns of embryo packing in Concholepas concholepas are linked to local temperature and oxygen requirements of the embryos, other strategies to adjust clutch size in order to assure oxygen provisioning to the embryos according to their requirements may occur. For instance, ovophagia and adelphophagia have been reported in many species of marine invertebrates that encapsulate embryos (i.e. Kohn \& Perron 1994, Collin 2003). It is not clear yet if intracapsular cannibalism is a plausible mechanism to reduce sibling competition for oxygen under adverse and unpredictable environmental conditions; however, the number of developing embryos increases with oxygen partial pressure in Acanthina monodon, suggesting that intrasibling consumption increases (Lardies \& Fernández 2002). C. concholepas embryos do not exhibit ovophagia or adelphophagia; this is clearly shown by the lack of change in the number of embryos during development in our laboratory experiments. Therefore, the clear response of females to temperature is critical, since clutch size does not seem to be regulated after deposition. More information on the relationship between embryo packing and environmental variables in species exhibiting ovophagia or adelphophagia during encapsulated development is needed to fully understand the set of mechanisms determining clutch size in species that encapsulate the embryos and to generalize our findings.

The alternative hypothesis to explain the $35 \%$ change in the number of embryos per unit of capsule size with a small change in temperature $\left(<1^{\circ} \mathrm{C}\right)$ is a change in the genetic structure of Concholepas concholepas populations on each side of the break. Although a break in the genetic structure over the short distance in which changes in embryo packing was observed is unlikely in a species exhibiting a long-lived larval stage (Palumbi 2003, Shanks et al. 2003), the break identified in the mean number of embryos packed per unit area of capsule coincides with the break in the genetic structure of C. concholepas reported between populations north and south of Coquimbo (about $30^{\circ} \mathrm{S}$; Guiñez et al. 1992; Fig. 1). Moreover, no genetic differences were detected among populations sampled south of the break, which also showed a homogeneous pattern of embryo packing, or in comparisons of northern populations among themselves (Guiñez 1992, Gallardo \& Carrasco 1996). However, ongoing studies question the existence of genetic differences among $C$. concholepas populations along the coast of Chile (L. Cardenas pers. comm.). Nevertheless, our results show a clear break in reproductive patterns of C. concholepas north and south of $30^{\circ} \mathrm{S}$ latitude. First, females from different sites of origin, but incubated at a common temperature, packed embryos as at their site of origin, which could suggest different behaviors among populations, regardless of temperature. Second, there was a clear effect of the origin of females on embryo developmental success at low and high temperatures. It is interesting to note that capsules deposited by females collected in the northern region showed no embryo development at the 2 lowest temperatures, which are extreme for the site of origin. Similarly, embryo development did not occur at $18^{\circ} \mathrm{C}$ in capsules deposited by females collected in the southern region. Although these results might be linked to genetic differences among populations, we cannot assume that 4 to 6 mo of acclimation was enough to delete the stable and predictable environmental signal of the site of origin (Hormazábal et al. 2004, Yuras et al. 2005). Therefore, more evidence on genetic structure of $C$. concholepas populations is needed to determine the influence of maternal genetic effects and environmental factors in shaping female behavior, as well as the interaction between these factors. Nevertheless, the existing evidence suggests that the reproductive behavior of populations of C. concholepas differs north and south of $30^{\circ} \mathrm{S}$, which may have important implications for the dynamics of the larval pool and the population dynamics of C. concholepas and, therefore, for management of this species.

Acknowledgements. We are grateful to M. Aguilera, I. Albornoz, A. Brante, M. Cifuentes, C. Inostroza, P. Pappalardo, R. Soto and F. Véliz for their help. We also thank R. Finke, J. Holl and S. Kimberlin for comments on the manuscript. Four anonymous reviewers made helpful comments and interesting suggestions to improve this manuscript. This study was fully supported by the Fondecyt 1020860 (M.F.) and 1990451 (J.M.C.). We also thank the Humboldt Foundation for their donation of equipment. M.F. acknowledges the FONDAPFondecyt grant 1501-0001 to the Center for Advanced Studies in Ecology and Biodiversity and the International Laboratory Dispersal and Adaptation in Marine Species (DIAMS). 


\section{LITERATURE CITED}

Baeza JA, Fernández M (2002) Active brood care in Cancer setosus (Crustacea: Decapoda): the relationship between female behavior, embryo oxygen consumption and the cost of brooding. Funct Ecol 16:241-251

Brante A (2006) An alternative mechanism to reduce intracapsular hypoxia in ovicapsules of Fusitron oregonensis. Mar Biol 149:269-274

Brante A, Fernández M, Eckerle L, Mark F, Pörtner H, Arntz W (2003) Reproductive investment in the crab Cancer setosus along a latitudinal cline: egg production, embryo losses and embryo ventilation. Mar Ecol Prog Ser 251: 221-232

Broitman BR, Navarrete SA, Smith F, Gaines SD (2001) Geographic variation of southeastern Pacific intertidal communities. Mar Ecol Prog Ser 224:21-34

Bustamante R, Castilla JC (1987) The shellfisheries in Chile: an analysis of 26 years of landings. Biol Pesq 16:79-97

Camus PA (1998) Estructura espacial de la diversidad en ensambles sésiles del intermareal rocoso en Chile centronorte: la diversidad local como un resultado de determinantes multiescala. Doctoral thesis, P. Universidad Católica de Chile, Santiago

Cancino JM, Gallardo JA, Torres F, Leiva G, Navarro JM (2000) Effects of sessile Protozoa on intracapsular oxygen tension and embryonic shell calcification in the muricid Chorus giganteus. Mar Ecol Prog Ser 200:141-148

Cancino JM, Gallardo JA, Torres FA (2003) Combined effects of dissolved oxygen concentration and water temperature on embryonic development and larval shell secretion in the marine snail Chorus giganteus (Gastropoda: Muricidae). Mar Biol 142:133-139

Castilla JC, Cancino J (1976) Spawning behaviour and egg capsules of Concholepas concholepas (Mollusca: Gastropoda: Muricidae). Mar Biol 37:255-263

Cohen CS, Strathmann R (1996) Embryos at the edge of tolerance: effects of environment and structure of egg masses on supply of oxygen to embryos. Biol Bull (Woods Hole) 190:8-15

Collin R (2003) Worldwide patterns in mode of development in calyptraeid gastropods. Mar Ecol Prog Ser 247:103-122

Crump M (1996) Parental care among the amphibians. Adv Study Behav 25:109-144

DiSalvo L (1988) Observations on the larval and post-metamorphic life of Concholepas concholepas (Bruguière, 1789) in laboratory culture. Veliger 30:358-368

Finke GR, Navarrete S, Bozinovic F (2007) Tidal regimes of temperate coasts and their influences on aerial exposure for intertidal organisms. Mar Ecol Prog Ser 343:57-62

Gallardo C (1973) Desarrollo intracapsular de Concholepas concholepas (Bruguière,1789) (Gastropoda Muricidae). Mus Nac Hist Nat 16:3-16

Gallardo C (1979) Ciclo vital del Muricidae Concholepas concholepas y consideraciones sobre sus primeras fases de vida en el bentos. Biol Pesq 12:79-80

Gallardo MH, Carrasco JM (1996) Genetic cohesiveness among population of Concholepas concholepas (Gastropoda, Muricidae) in southern Chile. J Exp Mar Biol Ecol 197:237-249

Editorial responsibility: Otto Kinne (Editor-in-Chief), Oldendorf/Luhe, Germany
Gallardo CS, Penchaszadeh PE (2001) Hatching mode and latitude in marine gastropods: revisiting Thorson's paradigm in the southern hemisphere. Mar Biol 138:547-552

Guiñez R, Gómez MV, Castilla JC (1992) Diferenciación genética poblacional en Concholepas concholepas (Bruguière, 1789) (Gastropoda, Muricidae) en su área de distribución centro-norte. Biol Pesq 21:31-41

Helly JJ, Levin LA (2004) Global distribution of naturally occurring marine hypoxia on continental margins. DeepSea Res 51:1159-1168

Hormazábal S, Shaffer G, Leth O (2004) The coastal transition zone off Chile. J Geophys Res 109(C01021), doi:10. 1029/2003JC00195

Kohn AJ, Perron FE (1994) Life history and biogeography: patterns in Conus. Oxford University Press, New York

Lardies MA, Fernández M (2002) Effect of oxygen availability in determining clutch size in Acanthina monodon. Mar Ecol Prog Ser 239:139-146

Lee CE, Strathmann R (1998) Scaling of gelatinous clutches: effects of siblings' competition for oxygen on clutch size and parental investment per offspring. Am Nat 151: 293-310

López DA, Varela C (1988) Manejo de reproductores y postura de cápsulas en Concholepas concholepas (Bruguière1789) (Gastropoda, Muricidae): una revisión de problemas y requerimientos de investigación. Biol Pesq $17: 21-30$

Manríquez PH, Castilla JC (2001) Significance of marine protected areas in central Chile as seeding grounds for the gastropod Concholepas concholepas. Mar Ecol Prog Ser 215:201-211

Navarrete SA, Wieters EA, Broitman B, Castilla JC (2005) Benthic-pelagic coupling and the oceanographic control of species interaction. Proc Natl Acad Sci 102(50): 18046-18051

Palumbi S (2003) Population genetics, demographic connectivity and the design of marine reserves. Ecol Appl 13(1):S146-S158

Perron FE, Corpuz GG (1982) Costs of parental care in the gastropod Conus pennaceus: age specific changes and physical constraints. Oecologia 55:319-324

Shanks AL, Grantham BA, Carr MH (2003) Propagule dispersal distance and the size and spacing of marine reserves. Ecol Appl 13(1):S159-S169

Strathmann R, Strathmann M (1982) The relationship between adult size and brooding in marine invertebrates. Am Nat 119:91-101

Strathmann R, Strathmann M (1995) Oxygen supply and limits on aggregation of embryos. J Mar Biol Assoc UK 75: $413-428$

Strub T, Mesías J, Montesinos V, Ruttlant J, Salinas S (1998) Coastal ocean circulation off western South America. In: Robinson AR, Brink KH (eds) The sea, Vol 11. John Wiley \& Sons, New York, p 273-313

Thorson G (1950) Reproductive and larval ecology of marine bottom invertebrates. Biol Rev 25:1-45

Yuras G, Ulloa O, Hormazábal S (2005) On the annual cycle of coastal and oceanic satellite chlorophyll off Chile $\left(18^{\circ}-\right.$ $40^{\circ} \mathrm{S}$ ). Geophys Res Let 32, L23604, doi: 10.1029/ 2005GL023946

Submitted: November 8, 2006; Accepted: May 9, 2007

Proofs received from author(s): September 21, 2007 